\title{
BETWEEN FREEDOM OF CONTRACT AND THE PRINCIPLE OF GOOD FAITH: AN INSIDE VIEW ON THE REFORM OF PRIVATE LAW OF KAZAKHSTAN
}

\begin{abstract}
Kamal K. Sabirov
sabirov.k@gmail.com

PhD student in Legal Sciences at L.N. Gumilyov Eurasian National University and Senior Researcher at the Institute of Legislation of the Republic of Kazakhstan. He is the author of more than 40 scientific articles in Kazakh and Russian languages in the field of private law issues and active participant of the law making process in Kazakhstan.

Venera T. Konussova konussova@mail.ru Deputy Director of the Institute of Legislation of the Republic of Kazakhstan; PhD in Legal Sciences. She is one of the developers of the Enterprise Code of the Republic of Kazakhstan and one of the authors of the Kazakhstan's law on advocacy.

Marat A. Alenov Iscc@mail.ru

Doctor of Law, Professor at L.N. Gumilyov Eurasian National University. He is one of the lead experts in Civil Procedure in Kazakhstan. He is the author of a large number of works in the field of private law and civil procedure.
\end{abstract}

\section{Abstract}

Over the years since Kazakhstan gained independence there have been cardinal changes in the country's economy associated with the inflow of foreign investments. These changes require the implementation of foreign experience in regulating economic relations and in particularly foreign contractual institutions. The International Financial Center "Astana" has started functioning in Kazakhstan since 2018. The acts of the International Financial Center are based on the principles and norms of law of England and Wales. In this regard, a largescale reform of the private law of the Republic of Kazakhstan was launched, aimed at identifying a number of civil-law ideas and designs that can be measured out in the Kazakh legislation from English law. The authors of this research are direct participants of the reform. This study is aimed at highlighting one of the issues considered within the framework of the reform of private law: strengthening the role of the principle of freedom of contract and the principle of good faith in the contract law of the Republic of Kazakhstan.

\section{Keywords}

Principle of good faith; freedom of contract; bona fide purchaser; legislation of Kazakhstan; private law of Kazakhstan

\section{How to cite this article}

Sabirov, Kamal K., Konussova, Venera T.; Alenov, Marat A. (2019). "Between freedom of contract and the principle of good faith: an inside view on the reform of private law of Kazakhstan". JANUS.NET e-journal of International Relations, Vol. 10, N. ${ }^{\circ} 2$, November 2019April 2020. Consulted [online] on the date of the last visit, https://doi.org/10.26619/1647$\underline{7251.10 .2 .10}$ 


\section{BETWEEN FREEDOM OF CONTRACT AND THE PRINCIPLE OF GOOD FAITH: AN INSIDE VIEW ON THE REFORM OF PRIVATE LAW OF KAZAKHSTAN}

Kamal K. Sabirov

Venera T. Konussova

Marat A. Alenov

\section{Introduction}

Despite the fact that the legal system of the Republic of Kazakhstan is the part of the Civil law, it was formed under the influence of the Soviet legal system and inherited many elements from it. The private law of the Republic of Kazakhstan is much like Russian private law. This is not surprising because both systems of private law are based on the model code of the CIS countries and also had a common history of formation within the framework of Soviet civil law. Nevertheless, more than 27 years have passed since the collapse of the Soviet Union and the private law of the CIS countries has altered appreciably (Akyn and Rakhymbai, 2017).

The reform of civil legislation has been ongoing for several years in the Russian Federation. A number of legislative acts were adopted to amend the Civil Code of the Russian Federation; in particular the obligation law was reformed. In the course of this reform some legal institutions of common law were implemented.

The International Financial Center "Astana" has started functioning in the Republic of Kazakhstan since 2018. The court of the International Financial Center relies on English contract law, in this connection it can be stated that the process of implementation of elements of common law into the legal system of the Republic of Kazakhstan is objective.

In connection with the beginning of the activity of the International Financial Center a large-scale reform of the legislation on the implementation of certain provisions of English and European law is under way. The participants of this reform are the authors of this article. At present, the Ministry of Justice developed a draft Concept for the future bill, which immediately aroused maximum discussion in the scientific and legal community (Konussova and Nesterova, 2016).

The purpose of the reform of civil legislation in the Republic of Kazakhstan is the modernization and development of private law. In this regard, it was necessary to compare approaches to the regulation of similar institutions, understand the legal logic and identify points of contact with it. And only on this basis to deny or to accept innovations that common law brings to the development of continental law. 
Due to the fact that the civil legislation of the Republic of Kazakhstan and the Russian Federation are largely similar, considerable attention was paid to the Russian experience. But according to the respective Kazakh legal scientists, not all the ideas embodied in the course of the reform of Russian private law can be considered as successful (Sulejmenov, 2016).

The reform of private law in the Russian Federation was confronted with conflicting opinions between supporters of English contract law and adherents of the classical German law school. Ultimately, during the reform an attempt to find a compromise, and amendments of both sides were taken into account.

During the preparation of the draft law various issues were raised, including the strengthening of the role of judicial practice, the development of the principle of good faith and the principle of freedom of contract, the introduction of the concept of "corporation" and legislative regulation of corporate relations, the development of holding legislation, the implementation of individual institutions of contract law (estoppel, liquidated damages, representations and warranties, indemnity clause, etc.). Thus, the reform envisaged quite revolutionary changes in the current legislation, which logically provoked resistance from conservative lawyers. In the end, some of the proposed innovations of the project had to be abandoned.

Within the framework of this article, it is proposed to discuss one of the elements of the reform of private law in the Republic of Kazakhstan, namely, the expansion of freedom of contract and as a counterbalance the strengthening of the principle of good faith.

Generally, in contract law there are two fundamental principles coexisting: the principle of freedom of contract and the principle of good faith in performance of the contract. And if English law more attention is paid to the principle of freedom of contract, in continental law the principle of good faith can be considered as a fundamental principle.

The freedom-of-contract doctrine implies that the parties of the contract have exactly the same obligations as those provided in their contract. The principle of good faith suggests that the parties of the contract have in front of each other a whole range of other obligations that arise not from the contract but from the requirement to act in good faith, as it is understood by this law and order. The principle of good faith can also exempt a party from the performance of its contract obligations if this rule of law considers it fair in this situation. Also, relying on the concerned principle the court can assign the responsibilities to the party that were not prescribed in the contract. All this contradicts the principle of freedom of the contract.

As a part of the ongoing reform of private law in Kazakhstan, there was an attempt to find a compromise between the principle of good faith and freedom of contract.

\section{Research Methods}

We undertook an analysis of existing legal norms, as well as the content of research materials of Kazakh, Russian, English, American and German specialists in the field of private law with the purpose of comprehensive analysis of some issues of the reform of private law of the Republic of Kazakhstan. During the research were used the works of both Kazakh and foreign authors - representatives of the German and English law 
schools. The methodological basis of the study includes: system analysis, comparison, theoretical and legal forecasting.

\section{Main results and discussion}

\section{Expanding The Limits Of Freedom Of Contract}

The historical roots of the principle of freedom of contract can be traced back to the Roman law that gave great priority to the free expression of the will of a person and denied any extraneous pressure. The principle of freedom of contract reached its peak in the middle of the nineteenth century after that it began to increasingly restrict itself to various legal orders.

In the United States freedom of contract is recognized as one of the constitutional rights of a citizen. The Supreme Court confirmed the strengthening of this right in the case of Frisbie v. United States, 157 U.S. 160 [1895] (Bernstein, D., 2008).

In general, we can distinguish three basic elements of freedom of contract: the freedom to conclude a contract, the freedom to choose a contract and the freedom to determine the content of the contract.

Here is how these elements are described in the comments to the Civil Code of the Republic of Kazakhstan: "Any person, at his own discretion and under no coercion from the outside, has the right: a) to decide whether to enter into or not to enter into a contract; b) to elect a partner who wish to conclude a contract; c) to determine the terms of the contract".

Controversial are the contracts which although not explicitly prohibited by law can be considered unethical or immoral. For example such contracts are the contracts on transplantation of human organs, which cause controversy among their supporters and opponents (Trebilcock, 1993). It is also necessary to touch on the issue of limiting the principle of freedom of contract. There are separate cases of restriction of freedom of contract even in English law. To such Craswell includes rules against liquated damages and rules that prohibits the enforcement of promises unsupported by consideration (Craswell, 1995).

The civil legislation of the Republic of Kazakhstan in paragraph 4 of Article 8 of the Civil Code of the Republic of Kazakhstan establishes general requirements for the behavior of citizens and legal entities. These evaluative concepts make it possible to establish general limits of the contract, limiting the parties from abuse.

In addition, the operation of the principle of freedom of contract has certain exceptions, assigned in legislative norms. Article 380 of the Civil Code of the Republic of Kazakhstan prohibits compulsion to conclude a contract, while clarifying that this does not apply to cases where the obligation to conclude a contract is provided for by the legislation or a voluntarily accepted obligation.

The principle of freedom of contract plays a key role in the development of economy and market relations. In the opinion of A. Didenko the contract serves as an instrument for "democratization" of the economy and through it the society (Didenko, 2000). The principle of freedom of contract is a logical continuation of the rights and freedoms guaranteed by the Constitution of the Republic of Kazakhstan from this point of view. 
As it follows from the Constitutional provisions in respect of the realization of the rights and freedoms of the citizens, a discretion method of regulating legislation is used, permitting what is not directly prohibited by the laws. The principle of discretion in relation to the realization by man of his rights and freedoms is assigned in the Article 29.2 of the Universal Declaration of Human and Civil Rights and Freedoms, which states that "everyone shall be subjected only such limitations that are determined by law solely for the purpose of securing due recognition and respect for the rights and freedoms of others".

Nevertheless, despite these rules the civil legislation of the Republic of Kazakhstan presupposes the mandatory nature of rules of contract law. Discretion of norms is presumed only if there is a special clause in it "unless otherwise provided by the agreement of the parties". The rules that don't have such clause are considered as mandatory.

On the other hand, we note that there are mandatory norms that underline their imperative nature with a special clause in the civil law. Currently, judicial practice shows that in disputable issues the issue of determining the nature of the norm is decided by the court.

In this regard, it seems natural to expand the principle of freedom of contract to improve the business environment. At the same time it is necessary to develop the natural limitations of the principle of freedom of contract through the principle of good faith.

Basin noted that the principles laid down in the civil legislation of the Republic of Kazakhstan are directly opposed to those basic principles on which the previous Civil Code of the Kazakh SSR was built (Basin, 2003). The soviet law proceeded from the fact that it is possible to do only what is permitted by the law. All this suggests that the discretionary norms of the contract law should be presented in the civil law in a larger extent than the mandatory norms. However, as pointed out by Klimkin, contract law, where the principle of freedom of contract should "work" fully, consists of mandatory norms for almost of $90 \%$ (Klimkin, 2014).

Thus, the civil legislation of the Republic of Kazakhstan proceeds from an approach that presupposes the mandatory norms if the norm does not directly establish its mandatory nature. In other words, "everything that is not permitted by law is prohibited". This restriction does not comply with the basic principles of the civil law; rights and freedoms guaranteed by the Constitution, as well as worldwide practice and it requires the changes.

In order to work out the best option for expanding the limits of freedom of contract, it is necessary to consider existing ways of limiting this principle. In the opinion of $\mathrm{S}$. V. Scriabin there are two main trends in the restriction of contractual freedom. The first implies the inclusion in civil law special clauses, for example, indicating the need to exercise civil rights in good faith, reasonably and fairly (Clause 4, Article 8 of the Civil Code of the Republic of Kazakhstan). The second implies the strengthening in the law of mandatory rules regarding the conditions of the certain types of contracts (Scriabin, 2003).

Analysis of civil legislation of the Republic of Kazakhstan shows the application of both ways of restricting freedom of contract. Restriction of freedom of contract by means of general reservations is typical for the norms on disputable transactions, and restriction of freedom of contract by direct restrictions for the rules on null transactions. 


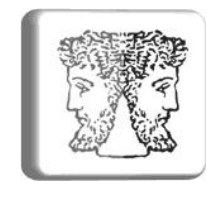

Based on the above, we believe that the extension of the principle of freedom of contract should not come from the idea of eliminating the existing limitations of the principle of freedom of contract, but from the strengthening of permissive beginnings in legislation.

Summarizing, the principle of freedom of contract is currently a fundamental principle of civil legislation. Nevertheless, in order to ensure the full protection of this principle in business transaction, it is necessary to significantly clarify the norms of civil legislation for strengthening the freedom of contract.

First, it is necessary to add to article 2 of the Civil Code of the Republic of Kazakhstan clarification that the freedom of contract is indeed the principle of civil law. Secondly, the protection of the principle of freedom of contract can be achieved by strengthening the discretion nature of the civil law.

The introduction of appropriate changes will significantly improve the civil legislation of the Republic of Kazakhstan and make it friendlier for the business environment.

\section{Strengthening The Principle Of Good Faith}

An indication of the requirements of good faith, justice and reasonableness appeared in the continental law under the influence of the French revolution which took the ideas of individual freedom, equality before the law and justice. These principles contributed to the development of social relations, ideas about the free expression of the will of the individual on the basis of contracts concluded with other persons. Almost all the systems of law of countries that identify themselves with the Civil law contain one or more provisions on good faith (Mackaay, 2011).

The principle of good faith also plays a central role in the law of mixed type (based on both common and civil law). For example, in the state of Louisiana the principle of good faith is applied in the law on general and conventional obligations, commercial law, family law, property law, etc. (Lovett, 2018).

There is practically no single definition of the concept of good faith in the law. But nevertheless this principle plays an important role, especially in the contract law (Podshivalov, 2018).

In the common law each contract implies the existence of good faith in its interpretation and enforcement. At the same time good faith is perceived as the absence of bad faith. In continental law good faith is observed as a category of morality and as a requirement that walks the line in the behavior.

The principle of good faith has a key role in the German law. German courts feel entitled and even obliged to interfere in the contractual relations when these relations are unfair to one of the parties. As for France, the principle of good faith in the contract relations was present in it since the Code of Napoleon.

In our opinion, the importance of the principle of good faith proved by the UK experience, where it has been unrecognized for a long period of time. As Mackaay notes, it was the English lawyers who resisted this doctrine most of all. Unlike the US law, where good faith is recognized in the pre-contractual legal relations, English law has treated this institution critically (Mackaay, 2011). For example, the right of the court to challenge the terms of the consumer contract ex post under the aegis of the fight against unfair contract terms was recognized in England only in the early 1990s and then only under the pressure 
of obligations to the EU. This followed by a lively discussion among European and British lawyers about how much economic integrity should prevail over cultural and national identity (Collins, 1994).

Let us cite a few positions of the English courts of the early 1990s that regulate the question of applying to the principle of good faith:

"There is no general doctrine of good faith in English law of contract.
The injured parties are free to act as they wish, provided that they
do not act in breach of the term of the contract" (JamesSpencer\&Co
Ltd. v. Tame Valley Padding Co Ltd. [1998]).

"The duty to negotiate in good faith is unworkable in practice" (Walford v. Miles [1992]).

In these cases, the court preferred the application of the principle of freedom of contract and judicial competition. This was the principal position of English law, which elevated the freedom of contract to the fundamental principle of the contract law for a long time. Meanwhile it is obvious to lawyers of the civil law tradition that the absolute freedom of the contract contradicts the fair consideration of the case.

However, the position of English courts in recent years has changed markedly. In the case of Yam Seng PTE Ltd v International Trade Corporation (ITC) Ltd. [2013], the court has spoken on the principle of good faith, recognizing that the traditional positions of English law regarding good faith is unreasonable (Poole, 2012).

"Good faith" in the US law was finally normatively defined in the codification in the Uniform Commercial Code (U.C.C.). In this document, an objective approach to determining honesty was applied to the definition of this concept. So it's a general concept that can be compared not only with the principle of good faith in Roman-German law, but also with evaluative concepts of rationality, justice and business ethics.

All this points to the importance of the principle of good faith.

The principle of good faith sum up business contracts, both in continental and common law. For example, paragraph 4 of Article 8 of the Civil Code of the Republic of Kazakhstan states that "good faith, reasonableness and fairness of actions of participants of legal relations are assumed". Thus, good faith is implied in each contract concluded, as well as the actions of the business entity. The principle of good faith is aimed at the formation of a model behavior, based on the prevailing in the society ideas about the honest image of thoughts, respect for the fair interests of others, the permissible degree of selfishness in legal behavior (Mikryukov, 2013). If we overview the principle of good faith from this perspective, it becomes clear that good faith underlies almost all private law and it is a general principle of the private law.

In the civil legislation of the Republic of Kazakhstan good faith is used in two meanings: objective and subjective. It's a traditional position of German legal doctrine which emphasizes good faith in the subjective meaning "guter Glauben" and in the objective meaning "Treu und Glauben" (Wieacker, 1956). 


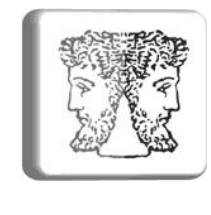

In an objective meaning good faith is understood as a "good conscience" i.e. a moral and ethical category and a principle of civil law based on moral and ethical beginnings. In the subjective meaning good faith is understood as a concrete, subjective state of a person and its compliance with certain criteria based on the moral ethical principle of good faith.

Also the reasonableness and fairness of actions of participants of civil legal relations are supposed according to paragraph 4 of Article 8 of the Civil Code of the Republic of Kazakhstan good faith. This norm marks good faith as a presumption.

It should also be taken into account that the category of good faith has a moral and ethical content. Therefore, in the civil legislation of the Republic of Kazakhstan there is no definition of the concept of "good faith" as in the case of such a definition, good faith could not be used as a moral assessment of the issue of protection of civil rights.

However, the question remains unresolved of whether it is possible to consider the requirements of good faith mentioned in the paragraph 4 of Article 8 of the Civil Code of Kazakhstan as a principle of the law. At the same time, good faith in the civil legislation of the Republic of Kazakhstan was not elevated to the category of the basic principles of civil law mentioned in the Article 2 of the Civil Code of the Republic of Kazakhstan. This causes a number of issues in the law enforcement practice.

Nevertheless, specification of the term "principle" in the text of the Civil Code of the Republic of Kazakhstan in relation to the requirements of good faith could remove most of the questions regarding the content of the basic principles of the civil law.

Taking into account the controversy over the issue of the relationship between the concepts of "principles" and "basic principles" it seems necessary to clarify in the text of the Civil Code that good faith is a general principle of private law. This would strengthen the principle of good faith in the civil legislation of the Republic of Kazakhstan and have a positive impact on civil circulation, significantly strengthening the protection of the rights of its participants.

Moreover, the consolidation of good faith as a principle of private law will significantly expand the scope of application of this institution, extending its effect to all civil legal relations, including relations on creation, change and termination of civil rights and obligations, protection of rights and interests.

Possible risk of such approach is that the courts will get a strong tool to regulate relations in the form of good faith. This risk can be compensated through control over the judicial practice which can be carried out by the Supreme Court of the Republic of Kazakhstan. Currently the Supreme Court of the Republic of Kazakhstan has experience of generalization and explanation of judicial practice. This experience can be extended to the application of the principle of good faith by the courts.

In the Republic of Kazakhstan, legislative explanations of the Supreme Court are attributed to the law in force and are adopted in the form of regulatory decisions, i.e. as acts containing the norms of law, although the scientific doctrine has not developed a consensus on the legal nature of such legal acts of the Supreme Court of the Republic of Kazakhstan.

In addition to legislative explanations the Supreme Court of the Republic of Kazakhstan also publishes collections with explanations of legal practice -Ylgi, which in Kazakh means "sample". Despite the fact that these collections are not official regulatory legal acts they 
have a respective opinion for the courts. Some Kazakhstan scientists put forward the idea of giving these collections certain legal force.

As a part of the ongoing reform of private law, we attempted to give these collections a recommendatory character, a kind of analogue of the case law (Konussova and Nesterova, 2016).

Unfortunately, this idea was not supported by Kazakhstani academic lawyers and at the moment it's no longer the part of the private law reform project.

However, the Supreme Court of the Republic of Kazakhstan may adopt regulatory decisions that clarify the lower courts the practice of applying certain norms. It is necessary to delineate the boundaries of the principle of good faith through these resolutions which ultimately protects against the abuse of this principle by the courts.

In consideration of the foregoing, it is necessary to include good faith into the Article 2 of the Civil Code of the Republic of Kazakhstan, as well as to clarify it as a principle of law. It should be borne in mind that the current article 8 of the Civil Code of the Republic of Kazakhstan limits the application of the principle of good faith. Thus it seems necessary to extend this principle to all civil relations including relations on the creation, change and termination of civil rights and obligations.

\section{Conclusions}

In the course of the reform of the private law of the Republic of Kazakhstan it became necessary to expand the principle of freedom of contract. In this regard, the developers of the draft of the future law came up with a choice of a possible solution to the issue.

Initially, the most logical was the option of revising the mandatory norms of the civil legislation of the Republic of Kazakhstan to expand the default beginnings of legislation.

However, this option required a lot of work to go beyond the project to implement certain provisions of English law and could not cover all the norms of the civil law. In addition, within the framework of one project, it is impossible to determine all possible options for abusing the principle of freedom of contract or the exceptions to this principle.

In this regard, it was decided to stay on two possible options for expanding the principle of freedom of contract.

Thus, a possible way of expanding the principle of freedom of contract is to transfer to the courts right to interpret controversial rules of the law that do not contain indications of mandatory or decretive nature. This option used in Russia and a number other states.

If the norm does not prohibit the approval of other provisions, nor a direct reference to the right of the parties to agree on other provisions, then the norm shall be determined by the interpretation of the court.

Alternatively it was possible to accept an approach that presumes the discretion nature of the law if it does not have a mandatory prescription. Nevertheless, this approach may entail cases of abuse of the principle of contractual freedom. However, this approach may entail cases of abuse of the principle of contractual freedom, as it will require, as in the first version of the revision of a large number of norms, in order to allow the parties to withdraw from it. Ultimately, it was decided to stop on this option. 
In order to smooth out possible negative effects from the expansion of the freedom of contract, the principle of good faith was also significantly strengthened. Expansion of the principle of freedom of contract will entail the inevitability of improving the system of checks from the unfair behavior of participants in civil turnover. In this regard, the principle of good faith may be a way to limit the principle of freedom of contract.

A significant difficulty was caused by the exclusion from the reform of private law issues of strengthening judicial practice. Nevertheless, even the current legislative mechanisms in the Republic of Kazakhstan can solve the problem of applying the principle of "good faith". In addition to regulatory changes it is necessary to improve systematically the culture of enforcement. The country has gained experience in generalizing and clarifying judicial practice under the leadership of the Supreme Court of the Republic of Kazakhstan, this experience can be extended applying the principle of good faith.

At present, the draft implementation of the norms and provisions of the English contract law into the civil law of the Republic of Kazakhstan is close to completion.

\section{References}

Civil Code of the Republic of Kazakhstan. (1994). Available at http://adilet.zan.kz/eng/docs/K940001000_

Kommentarij k Grazhdanskomu kodeksu Respubliki Kazahstan (Obshchaya chast'). [Comments to the Civil Code of the Republic of Kazakhstan (General part)] Ed.: Sulejmenov M., Basin Yu. (1999). Available at http://online.zakon.kz/Document/?doc_id=1019750

Universal Declaration of Human Rights. (1948). Available at http://www.un.org/en/universal-declaration-human-rights/index.html

Akyn, B., \& Rakhymbai, B. (2017). Implementation of Civil Service Reforms in Post-soviet Kazakhstan: Legal Framework, Opportunities and Challenges, 20(3), Journal of Legal, Ethical and Regulatory Issues. Available at https://www.abacademies.org/journals/journal-of-legal-ethical-and-regulatory-issueshome.html

Basin, Y.G. (2003). Izbrannye trudy po grazhdanskomu pravu [Selected Works on Civil Law]. Almaty: Adilet.

Bernstein, D. (2008). Freedom of Contract. In Liberty of Contract, in Encyclopedia of the Supreme Court of the United States (David S. Tanenhaus ed. 2008). George Mason Law \& Economics Research Paper No. 08-51. Available at SSRN: https://ssrn.com/abstract $=1239749$

Craswell, R. (1995) Freedom of contract. In: Posner E (ed) Chicago lectures in law and economics. Foundation Press, New York, pp. 81-103.

Collins, H. (1994). Good Faith in European Contract Law. Oxford Journal of Legal Studies, 14(2), pp.229-254.

Didenko, A.G. (2000). Kategoriya dogovora, ee mesto i znachenie v postsovetskom prave [The category of the treaty, its place and significance in post-Soviet law]. In Grazhdanskoe zakonodatel'stvo Respubliki Kazahstan: Stat'i, kommentarii, praktika 
[Civil legislation of the Republic of Kazakhstan: Articles, comments, practice]. Retrieved October 19, 2018, from http://online.zakon.kz/Document/?doc id=31455581

Konussova, V. \& Nesterova, Y. (2016). The improvement of civil legislation of the Republic of Kazakhstan based on the implementation of English law provisions. Pravo $i$ gosudarstvo, 3(72), pp.46-50.

Klimkin S.I. Grazhdanskoe pravo i cifry [Civil law and figures] (2014). Available at https://online.zakon.kz/Document/?doc_id=31560918

Lovett, John A. (2018). Good Faith in Louisiana Property Law, 78 La. L. Rev. Available at: https://digitalcommons.law.Isu.edu/lalrev/vol78/iss4/11

Mackaay, E. (2011). Good Faith in Civil Law Systems - A Legal-Economic Analysis. Available at SSRN: https://ssrn.com/abstract $=1998924$

Mikryukov, V.A. (2013). Princip dobrosovestnosti - novyj nravstvennyj ogranichitel' grazhdanskih prav [The principle of good faith - the new moral constraint on civil rights]. Zhurnal rossijskogo prava, 6.

Podshivalov, T. (2018). Protection of property rights based on the doctrine of piercing the corporate veil in the Russian case law. Russian Law Journal, 6(2), pp.39-72.

Poole, J. (2012). Casebook on Contract Law. OUP Oxford; 11 edition, p. 323

Skryabin S.V. Ogranichenie svobody dogovora [Restriction of freedom of contract]. (2003). Retrieved October 19, 2018, from http://online.zakon.kz/Document/?doc_id=30008052

Sulejmenov, M. (2016). Anglijskoe pravo i pravovaya sistema Kazahstana [English law and legal system of Kazakhstan]. Pravo i gosudarstvo, 3(72), pp.37-45.

Trebilcock, M. (1993). The limits of freedom of contract. Cambridge, Mass.: Harvard University Press, pp.33-36.

Wieacker, F. (1956). Zur rechtstheoretische Präzisierung des $\S 242$ BGB. Tübingen, J.C.B. Mohr (Siebeck). 